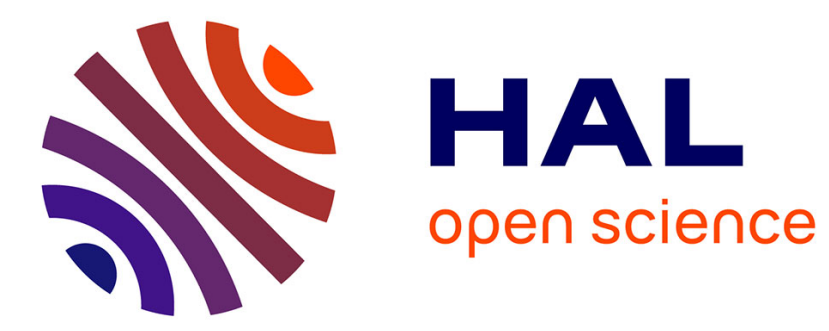

\title{
Nitrogen Cycling Driven By Organic Matter Export In The South Pacific Oxygen Minimum Zone
}

\author{
T. Kalvelage, G. Lavik, P. Lam, Sylvie Contreras, L. Arteaga, C. R. Loscher,
} A. Oschlies, A. Paulmier, L. Stramma, M. M. M. Kuypers

\section{- To cite this version:}

T. Kalvelage, G. Lavik, P. Lam, Sylvie Contreras, L. Arteaga, et al.. Nitrogen Cycling Driven By Organic Matter Export In The South Pacific Oxygen Minimum Zone. Nature Geoscience, 2013, 6 (3), pp.228-234. 10.1038/ngeo1739 . hal-00998635

\section{HAL Id: hal-00998635 https://hal.science/hal-00998635}

Submitted on 3 Sep 2014

HAL is a multi-disciplinary open access archive for the deposit and dissemination of scientific research documents, whether they are published or not. The documents may come from teaching and research institutions in France or abroad, or from public or private research centers.
L'archive ouverte pluridisciplinaire HAL, est destinée au dépôt et à la diffusion de documents scientifiques de niveau recherche, publiés ou non, émanant des établissements d'enseignement et de recherche français ou étrangers, des laboratoires publics ou privés. 


\section{Nitrogen cycling driven by organic matter export in the South}

\section{Pacific oxygen minimum zone}

Tim Kalvelage ${ }^{1}$, Gaute Lavik ${ }^{1}$, Phyllis Lam ${ }^{1}$, Sergio Contreras ${ }^{1,4}$, Lionel Arteaga ${ }^{2}$, Caroline Löscher $^{3}$, Andreas Oschlies ${ }^{2}$, Aurélien Paulmier ${ }^{1,5,6}$, Lothar Stramma ${ }^{2}$, Marcel M.M. Kuypers $^{1}$

${ }^{1}$ Max Planck Institute for Marine Microbiology, Bremen, Germany

${ }^{2}$ GEOMAR Helmholtz Centre for Ocean Research Kiel, Germany

${ }^{3}$ Institute for General Microbiology, Kiel, Germany

${ }^{4}$ Current address: Large Lakes Observatory, University of Minnesota Duluth, USA

${ }^{5}$ Current address: Laboratoire d'Etudes en Géophysique et Océanographie Spatiales,

Toulouse, France

${ }^{6}$ Current address: Instituto del Mar del Perú (IMARPE), Esquina Gamarra y General Valle S/N Chucuito Callao, Peru

Keywords: marine nitrogen cycle, export production, organic matter, nitrogen loss, N-deficit, anammox, secondary nitrite maximum, oxygen minimum zone, eastern tropical South Pacific, Peruvian upwelling system 

Oxygen minimum zones are major sites of oceanic nitrogen-loss, and have been expanding globally. Nitrogen-loss occurs mainly as the production of dinitrogen gas by denitrification or the so-called anammox process - the anaerobic ammonium oxidation with nitrite. Activity of anammox has been found more common in recent studies in the eastern tropical South Pacific, one of the largest oxygen minimum zones worldwide. As anammox requires substrates from multiple co-occurring nitrogen transformations, regulation of nitrogen-loss has to involve factors controlling overall nitrogen cycling, but which exactly remains unclear. Here, we present the most comprehensive nitrogen budget assessment for all major nitrogen fluxes to date for the eastern tropical South

10 Pacific oxygen minimum zone. Extensive ${ }^{15} \mathrm{~N}$-labelling experiments, nutrient measurements and export production modelling, together show that overall nitrogen cycling therein are tightly linked to the export of organic matter. Nitrogen-loss is most active over the productive shelf, fuelled by high rates of sinking organic matter and benthic ammonium release; then declines sharply offshore. These results highlight the importance of coastal oxygen minimum zones in oceanic nitrogen balance, and offer an empirical relationship for parameterization in biogeochemical models to more realistically assess the effects of climate change on oceanic carbon and nitrogen cycling.

Coastal upwelling of nutrient-rich deep water fuels high surface productivity at the

20 eastern boundaries of (sub)tropical oceans. The resultant export of organic matter stimulates strong microbial respiration in the subsurface. Combined with poor ventilation, permanently $\mathrm{O}_{2}$-deficient waters called oxygen minimum zones (OMZs) develop at mid-depths ${ }^{1,2}$. Ongoing, global expansion and intensification of OMZs will expectedly continue as anthropogenic pressures on marine environments grow gr, $^{3,5}$. 
Although constituting only $\sim 1 \%\left(\mathrm{O}_{2} \leq 20 \mu \mathrm{mol} \mathrm{kg}^{-1}\right)$ of global ocean volume ${ }^{6}$, OMZs have a profound impact on oceanic nitrogen $(\mathrm{N})$ balance as they account for $\sim 20-40 \%$ of global oceanic $\mathrm{N}$-loss ${ }^{7}$. Ocean de-oxygenation might enlarge the ocean volume subject to $\mathrm{N}$ $\operatorname{loss}^{8}$, exacerbate N-limitation of phytoplankton, and reduce the ocean's capacity to attenuate rising atmospheric carbon dioxide. Assessing the effects of expanding OMZs on the future

30 ocean's nutrient balance, however, remains speculative, as biogeochemical models do not reproduce present-day global patterns of N-loss $9,10,11$. A major deficiency of those models appears to be the poor representation of coastal regions; whereas an increasing number of studies indicates that $\mathrm{N}-$ loss in shelf OMZs ${ }^{12,13,14}$, coastal-offshore OMZ water mass exchange ${ }^{15}$ and OMZ-sediment interactions ${ }^{16}$ play more important roles on the overall N35 budget.

Based on the observed accumulations of nitrite $\left(\mathrm{NO}_{2}{ }^{-}\right)$and associated $\mathrm{N}$-deficits, most $\mathrm{N}$-loss in OMZ waters has traditionally been attributed to heterotrophic denitrification ${ }^{17,18,19}$, the stepwise reduction of nitrate $\left(\mathrm{NO}_{3}{ }^{-}\right)$to gaseous dinitrogen $\left(\mathrm{N}_{2}\right)$. Recent studies have, however, often failed to detect significant denitrifying activity in OMZs; rather, anammox

40 has more commonly been identified as a major $\mathrm{N}_{2}$-forming pathway in these environments $^{12,13,14,20}$.

The regulation of N-loss activity including anammox is not fully understood. Anammox requires $\mathrm{NH}_{4}{ }^{+}$and $\mathrm{NO}_{2}{ }^{-}$. Sources and sinks of both compounds have been identified in the OMZs, including aerobic $\mathrm{NH}_{3}$ and $\mathrm{NO}_{2}{ }^{-}$oxidation, as well as anaerobic $\mathrm{NO}_{3}{ }^{-}$

45 reduction to $\mathrm{NO}_{2}^{-}$and dissimilatory $\mathrm{NO}_{3}{ }^{-} / \mathrm{NO}_{2}{ }^{-}$reduction to $\mathrm{NH}_{4}{ }^{+}$(DNRA) ${ }^{14,15,21,22}$. Surprisingly, $\mathrm{O}_{2}$ sensitivity assays show that these processes in $\mathrm{OMZ}$ waters share a large overlapping range of $\mathrm{O}_{2}$ concentrations $\left(>0-20 \mu \mathrm{mol} \mathrm{L}^{-1}\right)$ in which they can co-occur, implying that within this range, controlling factors other than $\mathrm{O}_{2}$ are more important ${ }^{23,24}$. Enhanced autotrophic and heterotrophic N-cycling activity in the upper $\mathrm{OMZ}^{13,14,20,21}$, and 
50 generally elevated anammox rates usually measured in coastal versus offshore OMZs ${ }^{6}$, suggest that $\mathrm{N}$-loss might ultimately be regulated by export production of organic matter.

To test this hypothesis, we conducted a large-scale survey of N-cycling rates, functional gene abundances, chlorophyll, nutrient and $\mathrm{O}_{2}$ concentrations, as well as modelled export production, throughout the eastern tropical South Pacific (ETSP), one of the three

55 major OMZs in the world.

\section{Dissolved Inorganic Nitrogen in the South Pacific Oxygen Minimum Zone}

Consistent with past observations in the $\mathrm{ETSP}^{18,26}$, pronounced secondary $\mathrm{NO}_{2}{ }^{-}$ maxima were found in the offshore $\mathrm{OMZ}$ between $10^{\circ} \mathrm{S}$ and $18^{\circ} \mathrm{S}$ (supplementary Fig. 1),

60 extending up to 100's km westward with maximum concentrations of $\sim 11 \mu \mathrm{mol} \mathrm{L}{ }^{-1}$. Based on the spatial distribution of measured $\mathrm{O}_{2}$, the lower OMZ boundary occurred at $\sim 600 \mathrm{~m}$ on average near the Peruvian shelf (Figs S1-2). Henceforth, this is used as a depth cut-off to differentiate coastal OMZ stations, where the $\mathrm{OMZ}$ is in direct contact with sediments and benthic $\mathrm{N}$-fluxes $(<600 \mathrm{~m})$, from all others that are defined as offshore OMZ stations.

65 Integrated over the thickness of the OMZ (defined by $\mathrm{O}_{2} \leq 15 \mu \mathrm{mol} \mathrm{L}^{-1}$ where N-loss activity remains detectable in $\mathrm{O}_{2}$-sensitivity assays ${ }^{24}$; Figs $\left.1 \mathrm{~b}, \mathrm{~S} 2\right), \mathrm{NO}_{2}{ }^{-}$concentrations reached $>2$ mol m${ }^{-2}$ in the offshore region (Fig. 1d). Concentrations of $\mathrm{NH}_{4}{ }^{+}$were low $\left(<0.25 \mu \mathrm{mol} \mathrm{L}^{-1}\right)$ throughout the OMZ, but could be $\geq 0.5 \mu \mathrm{mol} \mathrm{L} \mathrm{L}^{-1}$ over the shelf and near the upper OMZ boundary further offshore. Deeper in the offshore OMZ, plumes of elevated $\mathrm{NH}_{4}{ }^{+}$

70 concentrations $\left(\leq \sim 3 \mu \mathrm{mol} \mathrm{L}^{-1}\right)$ sometimes occurred (supplementary Fig. 1), resulting in high depth-integrated values (Fig. 1e).

Offshore OMZs were characterized by severe N-deficits, expressed here as strongly negative $\mathrm{N}^{*}$ with minima from $-8 \mu \mathrm{mol} \mathrm{N} \mathrm{L}{ }^{-1}$ at $3.58^{\circ} \mathrm{S}$ down to $-32 \mu \mathrm{mol} \mathrm{N} \mathrm{L}{ }^{-1}$ at $16^{\circ} \mathrm{S}$. Depth-integrated values of $\mathrm{N}^{*}$ (Fig. 1e) and $\mathrm{NO}_{2}{ }^{-}$were significantly correlated (Spearman 
$75 \mathrm{R}=-0.61, \mathrm{p} \leq 0.001)$. The southward intensification of both $\mathrm{NO}_{2}{ }^{-}$maxima and $\mathrm{N}^{*}$ minima likely reflects the accumulated effects of time-integrated microbial activity in OMZ waters that advect poleward along the continental slope with the Peru-Chile Undercurrent ${ }^{27,28}$. Over the Peruvian shelf between $12^{\circ} \mathrm{S}$ and $14^{\circ} \mathrm{S}$, extreme N-deficits $\left(\mathrm{N}^{*}\right.$ down to $-60 \mu \mathrm{mol} \mathrm{L}{ }^{-1}$, Supplementary Fig. 1) were detected along with the presence of hydrogen sulphide $\left(\mathrm{H}_{2} \mathrm{~S}\right)$.

80 These stations are not further considered in the remaining discussions unless otherwise indicated, as the resident microbial communities and processes profoundly differ from typical OMZ scenarios (Schunck et al. submitted.).

\section{Sources of Nitrite}

Nitrite in the OMZs can be generated by $\mathrm{NH}_{3}$ oxidation, the first step of nitrification; or by the reduction of nitrate to nitrite ${ }^{6,21,22}$. Ammonia oxidation has been identified as an important $\mathrm{NO}_{2}{ }^{-}$source in the Peruvian OMZ, that is active under near-anoxic conditions ${ }^{21,23,29}$. Our measured rates of $\mathrm{NH}_{3}$ oxidation generally peaked at the base of the oxycline ( $\left.\sim 90 \mathrm{nmol} \mathrm{N} \mathrm{L} \mathrm{d}^{-1}\right)$, decreased to detection limit at the stations furthest offshore,

90 and were not detectable in the core of the OMZ (Tables 1 and S2). The presence of both archaeal and bacterial ammonia-oxidizers is verified by the detection of their biomarker functional genes encoding ammonia monooxygenase subunit A (Tables 1 and S3).

Integrated over the thickness of the $\mathrm{OMZ}, \mathrm{NO}_{2}{ }^{-}$production via $\mathrm{NH}_{3}$ oxidation increased from undetectable at the westernmost stations to $\leq 4.7 \mathrm{mmol} \mathrm{NO}_{2}^{-} \mathrm{m}^{-2} \mathrm{~d}^{-1}$ near the

95 coast (Fig. $2 \mathrm{a}$; supplementary Table 1$)$. For the entire OMZ volume examined $\left(\sim 5.5 \times 10^{5}\right.$ $\left.\mathrm{km}^{3}\right), \mathrm{NH}_{3}$ oxidation is estimated to produce $\sim 3.8 \mathrm{Tg} \mathrm{N} \mathrm{y}^{-1}$ of $\mathrm{NO}_{2}^{-}$, with $24 \%$ attributed to coastal OMZ ( $\leq 600 \mathrm{~m})$ and 76\% offshore (>600 m) (Fig. 3). Although significant rates have also been reported for the surface mixed layer in the $\mathrm{ETSP}^{30}$, the mixed layer was not included in the current OMZ budget. 
majority came from $\mathrm{NO}_{3}{ }^{-}$reduction to $\mathrm{NO}_{2}{ }^{-}$, consistent with previous findings in the Peruvian, Namibian and Arabian Sea OMZs ${ }^{15,21,22}$. Apart from its association with anammox, $\mathrm{NO}_{3}{ }^{-}$reduction to $\mathrm{NO}_{2}{ }^{-}$is the first step in denitrification and DNRA, and $\mathrm{NO}_{3}{ }^{-}$is the next preferred terminal electron acceptor after $\mathrm{O}_{2}$ for the oxidation of organic matter. $\mathrm{NO}_{3}{ }^{-}$

105 reduction was detected throughout the $\mathrm{OMZ}$ at all investigated stations; it reached a maximum $\left(\sim 1 \mu \mathrm{mol} \mathrm{N} \mathrm{L}{ }^{-1} \mathrm{~d}^{-1}\right)$ over the central shelf, but dropped to $\sim 10 \mathrm{nmol} \mathrm{N} \mathrm{L} \mathrm{d}^{-1}$ at the westernmost offshore stations (Table 1).

Depth-integrated rates showed similarly declining trend offshore (Fig. 2c;

supplementary Table 1). Integration over the whole region yields an annual $\mathrm{NO}_{3}{ }^{-}$reduction of

$110 \sim 49 \mathrm{Tg} \mathrm{N}$, of which $29 \%$ occurs in the coastal OMZ and $71 \%$ offshore (Fig. 3). Like previous observations from the Peruvian ${ }^{23}$ and the Arabian $\mathrm{Sea}^{15} \mathrm{OMZs} \mathrm{NO}_{3}{ }^{-}$reduction significantly correlated with depth-integrated $\mathrm{NO}_{2}{ }^{-}$concentrations (Spearman $\mathrm{R}=0.71, \mathrm{p} \leq 0.001$ ) (Table 2), which indicates that $\mathrm{NO}_{3}{ }^{-}$reduction is a major contributor to the secondary $\mathrm{NO}_{2}{ }^{-}$maxima.

\section{Sinks of Nitrite}

Nitrite oxidation, the second step in nitrification, was most active in the upper OMZ throughout the ETSP. Its activity was detected deeper into the OMZ than $\mathrm{NH}_{3}$ oxidation, consistent with earlier reports ${ }^{23,29}$. Nitrite oxidation rates were highest $\left(928 \mathrm{nmol} \mathrm{N} \mathrm{L}^{-1} \mathrm{~d}^{-1}\right)$ over the Peruvian shelf despite low $\mathrm{O}_{2}$ levels (Table 1), and declined sharply to $\leq \sim 20 \mathrm{nmol} \mathrm{N}$ $120 \mathrm{~L}^{-1} \mathrm{~d}^{-1}$ along the furthest offshore transect. Although $\mathrm{NO}_{2}{ }^{-}$oxidation is believed to require $\mathrm{O}_{2}$, this process has been detected at $<1-2 \mu \mathrm{mol} \mathrm{O}_{2} \mathrm{~L}^{-1}$ in the Peruvian ${ }^{23,29}$ and Namibian $\mathrm{OMZs}^{22} . \mathrm{O}_{2}$ sensitivity assays $\left(\sim 1-25 \mu \mathrm{mol} \mathrm{L}^{-1}\right)$ at two stations further demonstrated only a moderate attenuation by low $\mathrm{O}_{2}$ (at most $\sim 50 \%$ activity reduction at $<1 \mu \mathrm{mol} \mathrm{L}^{-1}$ ) 
(supplementary Fig. 3), which agrees well with observations in the Namibian $\mathrm{OMZ}^{22}$.

125 Clearly, $\mathrm{NO}_{2}{ }^{-}$oxidizers are well adapted to $\mathrm{O}_{2}$-deficient environments.

$\mathrm{NO}_{2}{ }^{-}$-supply from $\mathrm{NH}_{3}$ oxidation, the first step of nitrification, is thought to constrain $\mathrm{NO}_{2}{ }^{-}$oxidation rates. Despite the significant correlation between $\mathrm{NH}_{3}$ and $\mathrm{NO}_{2}{ }^{-}$oxidation rates (Spearman $\mathrm{R}=0.73, \mathrm{p} \leq 0.001)$ (Table 2$), \mathrm{NO}_{2}{ }^{-}$oxidation in the ETSP OMZ exceeded those of $\mathrm{NH}_{3}$ oxidation often by more than tenfold (Fig. 2a,b; supplementary Table 1,2).

130 Similar observations in the OMZs off Namibia ${ }^{22}$ and Peru ${ }^{23,29}$, indicate a decoupling of the two steps of nitrification in $\mathrm{O}_{2}$-deficient systems. A likely alternative $\mathrm{NO}_{2}{ }^{-}$source is $\mathrm{NO}_{3}{ }^{-}$ reduction.

Based on modeled N-fluxes a $\mathrm{NO}_{2}{ }^{-}$"shunt", in which $45-74 \%$ of the $\mathrm{NO}_{3}{ }^{-}$reduced to $\mathrm{NO}_{2}{ }^{-}$by "denitrifying" micro-organisms is re-oxidized by aerobic $\mathrm{NO}_{2}{ }^{-}$oxidizers, has been

135 proposed for the $\mathrm{ETSP}^{31}$. In agreement, our annual rates of $\mathrm{NO}_{2}{ }^{-}$oxidation for the coastal (7 $\left.\operatorname{Tg~N~y}{ }^{-1}\right)$ and offshore $\mathrm{OMZ}\left(23 \mathrm{Tg} \mathrm{N} \mathrm{y}^{-1}\right)$ are equivalent to $51 \%$ and $65 \%$, respectively, of $\mathrm{NO}_{3}{ }^{-}$reduction (Fig. 3). The strong correlation between the two processes (Spearman $\mathrm{R}=0.75, \mathrm{p} \leq 0.001)$ (Table 2) indicates a close coupling between $\mathrm{NO}_{2}{ }^{-}$oxidation and $\mathrm{NO}_{3}{ }^{-}$ reduction in the ETSP OMZ.

140 Meanwhile, only sporadic and low rates of DNRA $\left(\leq 1.3 \mathrm{nmol} \mathrm{L}^{-1} \mathrm{~d}^{-1}\right)$ were detected during our sampling period (Table 1). A general lack of detectable $n r f A$, a key functional gene encoding for the cytochrome $c \mathrm{NO}_{2}{ }^{-}$reductase corroborates these results (Table 1). DNRA appears to exhibit a high degree of spatio-temporal variability, with similarly low rates measured on the Namibian shelf ${ }^{22}$, but with tenfold greater rates and $n r f A$ gene 145 abundance than observed in the OMZs off Peru ${ }^{21}$ and Oman ${ }^{14}$. Hence, we cannot exclude DNRA as a significant $\mathrm{NO}_{\mathrm{x}}{ }^{-}$-sink for and $\mathrm{NH}_{4}{ }^{+}$-source in the ETSP at other times.

\section{Nitrogen-Loss Activities}


At the time of our sampling, denitrification, expressed as the production of ${ }^{30} \mathrm{~N}_{2}$ from

${ }^{15} \mathrm{NO}_{\mathrm{x}}$, was generally non-detectable. Low rates of denitrification $\left(\sim 2-5 \mathrm{nmol} \mathrm{L}{ }^{-1} \mathrm{~d}^{-1}\right)$ were measured in three samples from the Peruvian shelf OMZ (Tables 1, S2). Substantially higher rates were detected in few samples containing measurable amounts of $\mathrm{H}_{2} \mathrm{~S}$ (Fig. 2e;

supplementary Tables 1,2 ), suggesting a coupling with $\mathrm{H}_{2} \mathrm{~S}$ oxidation (ref. 32; Schunck et al. submitted.). In contrast to the conclusion drawn by a recent study ${ }^{33}$, water-column 155 denitification was only of minor importance $(<<1 \%$ total $\mathrm{N}-$ loss $)$ for the overall N-budget in the ETSP OMZ (supplementary information).

$\mathrm{N}_{2}$ production attributed to anammox was detected at all stations except the two furthest offshore, consistentent with previous studies in the $\operatorname{ETSP}^{13,20,34}$, . Anammox activity was often enhanced in the upper OMZ and markedly elevated in the bottom waters over the

160 shelf and upper continental slope. Rates were highest $\left(\leq \sim 225 \mathrm{nmol} \mathrm{N} \mathrm{L}^{-1} \mathrm{~d}^{-1}\right)$ over the central shelf $\left(10^{\circ} \mathrm{S}-16^{\circ} \mathrm{S}\right)$ and declined by two orders of magnitude westward (Table 1$)$. The presence of anammox bacteria was verified by the detection of their characteristic hydrazine $\left(\mathrm{N}_{2} \mathrm{H}_{4}\right)$ oxidoreductase genes (hzol and 2) throughout the OMZ; whereas denitrifier-nirS, encoding for the cytochrome $c d_{1}$-containing $\mathrm{NO}_{2}{ }^{-}$reductase, was generally not detectable (Tables 2 , $165 \mathrm{~S} 3)$.

Depth-integrated anammox rates were $>10 \mathrm{mmol} \mathrm{N} \mathrm{m}^{-2} \mathrm{~d}^{-1}$ on the central shelf, similar to previous findings ${ }^{13}$, and $<1 \mathrm{mmol} \mathrm{N} \mathrm{m}^{-2} \mathrm{~d}^{-1}$ at the furthest offshore stations (Fig. 2d; supplementary Table 1). Altogether, anammox accounts for an annual N-loss of $\sim 10 \mathrm{Tg}$ in an area of $1.2 \times 10^{6} \mathrm{~km}^{2}$, which is at the lower end of earlier estimates for the ETSP (9-26 $\left.170 \quad \operatorname{Tg~N~y}^{-1}\right)^{13,18,23,35}$.

Flux measurements of dissolved inorganic nitrogen and $\mathrm{N}_{2}$ made just prior to our sampling demonstrate that the sediments underlying the OMZ are additional sites of N-loss ${ }^{16}$. Combined with reaction-diffusion modeling, anammox and denitrification were shown to be 
active N-sinks in the Peruvian coastal sediments. Based on the reported sedimentary $\mathrm{NO}_{\mathrm{x}}{ }^{-}$

175 fluxes and $\mathrm{NO}_{\mathrm{x}}{ }^{-}$partitioning between anammox, denitrification, and $\mathrm{DNRA}^{16}$, we estimate a loss of $1 \mathrm{Tg} \mathrm{N} \mathrm{y}^{-1}$ from sediments in contact with the OMZ bottom waters (Fig. 3).

Conventionally, the accumulation of $\mathrm{NO}_{2}^{-}$in $\mathrm{OMZ}$ waters has been interpreted as signs of active N-loss, and thus, is targeted by most field-sampling campaigns ${ }^{17,18,19,20,23,26,29}$. Our data contradict this interpretation. Unlike $\mathrm{NO}_{2}{ }^{-}$, depth-integrated anammox rates did not 180 reveal any meridional trends, but decreased from shelf to offshore. Depth-integrated anammox rates and $\mathrm{NO}_{2}{ }^{-}$concentration were only moderately correlated (Spearman $\mathrm{R}=0.64$, $\mathrm{p}<0.001$ ) (Table 2). Furthermore, significant correlations between volumetric rates and $\mathrm{NO}_{2}{ }^{-}$ concentrations were only observed for the shelf OMZ (Spearman $\mathrm{R}=0.72, \mathrm{p}<0.001$ ) and not offshore (Spearman, $\mathrm{p}>0.5$ ). $\mathrm{NO}_{2}{ }^{-}$accumulation offshore probably resulted from a greater

185 persistence of $\mathrm{NO}_{3}{ }^{-}$reduction to $\mathrm{NO}_{2}{ }^{-}$compared to other $\mathrm{NO}_{2}{ }^{-}$-consuming processes in a poorly ventilated region, where the net $\mathrm{NO}_{2}{ }^{-}$gain was about five times higher compared to the coastal OMZ (11.4 and 2.2 $\mathrm{Tg} \mathrm{N} \mathrm{y}^{-1}$, respectively).

Ongoing water column $\mathrm{N}$-loss cannot be deduced simply from the intensity of $\mathrm{N}^{*}$ minima, as shown by the lack of significant correlation (Spearman $\mathrm{p}>0.05$ ) between 190 anammox activity and $\mathrm{N}^{*}$ (Table 2 ). While the depth-integrated $\mathrm{N}$-deficit is strongest (most negative $\mathrm{N}^{*}$ ) offshore, anammox activity is highest over the shelf and upper continental slope. Though comprising only $10 \%$ of the area covered and merely $4 \%$ of the sampled OMZ volume, coastal OMZ waters contribute as much as 30\% of the total N-loss (Fig. 3). Meanwhile, N-deficits in coastal OMZ waters amount to only $5 \%(4 \mathrm{Tg} \mathrm{N})$ of the total N195 deficit $(71 \mathrm{Tg} \mathrm{N})$. Hence, the large $\mathrm{N}$-deficit offshore most likely results from horizontal advection of $\mathrm{N}$-deficient shelf waters ${ }^{21}$ that accumulate due to a long residence time in the offshore OMZ ( $\sim 10$ y based on $\mathrm{N}^{*}$ and measured N-loss). This is analogous to to recent observations made in the Arabian Sea: substantial $\mathrm{NO}_{2}{ }^{-}$accumulation and low N-loss activity 
in the central basin, compared to the rapid N-loss over the adjacent productive Omani shelf $^{14,15}$.

\section{Sources of Ammonium}

$\mathrm{N}$-loss driven by anammox requires $\mathrm{NH}_{4}{ }^{+}$, which usually does not accumulate in OMZs. Ammonium concentrations can be kept low by a tight coupling between $\mathrm{NH}_{4}{ }^{+}$

205 production and consumption processes, while the $\mathrm{NH}_{4}{ }^{+}$released at the reported remineralization rates may already be sufficient to fuel anammox. Major sources of $\mathrm{NH}_{4}{ }^{+}$are water-column organic matter remineralization and sedimentary $\mathrm{NH}_{4}{ }^{+}$release.

DNRA and organic matter ammonification are active benthic $\mathrm{NH}_{4}{ }^{+}$sources off the coast of Peru. During two preceding cruises (M77-1 and 2) to the $\mathrm{ETSP}^{16}$, large $\mathrm{NH}_{4}{ }^{+}$fluxes

$210 \quad\left(\sim 0.5-4 \mathrm{mmol} \mathrm{m}^{2} \mathrm{~d}^{-1}\right)$ from sediments into the overlying OMZ waters were measured on a cross-shelf transect at $11^{\circ} \mathrm{S}$. The often enhanced anammox activity in the coastal OMZ bottom waters suggests a strong influence from $\mathrm{NH}_{4}{ }^{+}$diffusing out of the sediments ${ }^{13,36}$. Assuming an average benthic $\mathrm{NH}_{4}{ }^{+}$flux of $\sim 2 \mathrm{mmol} \mathrm{m}^{-2} \mathrm{~d}^{-1}$ and a typical anammox rate of $\sim 4 \mathrm{mmol} \mathrm{NH}_{4}{ }^{+} \mathrm{m}^{-2} \mathrm{~d}^{-1}$ for the Peruvian coastal waters, the underlying sediments could supply

$215 \sim 50 \%$ of the $\mathrm{NH}_{4}{ }^{+}$needed for the anammox rates observed. Clearly, additional $\mathrm{NH}_{4}{ }^{+}$sources are necessary to fulfil the remaining requirements for anammox, especially in offshore OMZ waters, which are spatially decoupled from the sediments.

Based on the measured $\mathrm{NO}_{3}{ }^{-}$reduction rates, subsequent ammonification of Redfieldian organic matter generates $65 \%$ and $73 \%$ of the $\mathrm{NH}_{4}{ }^{+}$needed for anammox in the coastal and offshore OMZs, respectively (Fig. 3). These are likely underestimates, considering the observed preferential $\mathrm{N}$-degradation of organic matter via $\mathrm{NO}_{3}{ }^{-}$respiration under suboxic conditions ${ }^{37}$. Whether the reduction of $\mathrm{NO}_{3}{ }^{-}$is directly coupled to the 
oxidation of organic matter, or indirectly via a recently proposed cryptic sulphur cycle ${ }^{38}$, could not be discerned at this point.

enhanced near the upper OMZ boundary, and would support the high anammox and $\mathrm{NH}_{3}$ oxidation activity observed ${ }^{13,14,15,20,21,23}$. On average, $\sim 40 \%$ of their combined $\mathrm{NH}_{4}{ }^{+}$demands are supplied by $\mathrm{NO}_{3}{ }^{-}$reduction, with the remainder possibly coming from microaerobic organic matter remineralization ${ }^{20}$. The activity of $\mathrm{O}_{2}$-dependent nitrification at non-detectable

$230 \mathrm{O}_{2}$ concentrations in $\mathrm{OMZs}$ indicates that microaerobic respiration proceeds even at nanomolar $\mathrm{O}_{2}$ levels, in accordance with an apparent half-saturation coefficient of $<20 \mathrm{nmol}$ $\mathrm{L}^{-1}$ previously reported for microaerobic respiration in these waters ${ }^{39}$. High $\mathrm{O}_{2}$ consumption rates, mainly attributable to heterotrophic respiration, and genes encoding for terminal respiratory oxidases with high $\mathrm{O}_{2}$-affinities were detected in the ETSP on the same

235 expedition (Kalvelage et al. unpubl.). While there are suggestions that $\mathrm{O}_{2}$ is efficiently depleted down to the limits of microaerobic respiration in the OMZ core ${ }^{40}$, regular intrusions of more oxygenated surface waters or mixing events, such as those related to eddies ${ }^{41}$, may sustain aerobic microbial activity in the upper OMZ.

\section{Linking Surface Productivity and Sub-surface Nitrogen Cycling}

Depth-integrated anammox rates correlated strikingly well with $\mathrm{NO}_{3}{ }^{-}$reduction, $\mathrm{NO}_{2}{ }^{-}$ oxidation and $\mathrm{NH}_{3}$ oxidation (Spearman $\mathrm{R}=0.88,0.86$ and 0.75 , respectively; $\mathrm{p} \leq 0.001$ ), indicating a common controlling factor for their concerted activity. Our data suggest that Ncycling processes in the $\mathrm{OMZ}$ are tightly coupled to the export of organic matter.

Export of organic matter at the base of the euphotic zone was estimated from net primary production (NPP) ${ }^{42}$ and the ratio of export-to-total primary production (ef-ratio $)^{43}$. At the time of sampling, NPP was up to $\sim 3$ g organic $\mathrm{C}\left(\mathrm{C}_{\mathrm{org}}\right) \mathrm{m}^{-2} \mathrm{~d}^{-1}$ near the coast and 
decreased to $<0.5 \mathrm{~g} \mathrm{C}_{\text {org }} \mathrm{m}^{-2} \mathrm{~d}^{-1}$ further offshore, values typical for the Peruvian upwelling system $^{44}$. Computed ef-ratios ranged from 0.16 (low-NPP sites) to 0.42 (high-NPP sites). The resulting $\mathrm{N}$-export production rates (converted from measured $\mathrm{C}: \mathrm{N}=7.2$ of surface particulate organic matter) were $>10 \mathrm{mmol}$ organic $\mathrm{N}\left(\mathrm{N}_{\mathrm{org}}\right) \mathrm{m}^{-2} \mathrm{~d}^{-1}$ over the shelf and in the order of $\sim 1$ mmol $\mathrm{N}_{\text {org }} \mathrm{m}^{-2} \mathrm{~d}^{-1}$ at the stations furthest offshore (Fig. 2f; supplementary Table 1). Export production was highly correlated to depth-integrated rates of anammox, $\mathrm{NO}_{3}{ }^{-}$reduction and $\mathrm{NO}_{2}{ }^{-}$oxidation (Spearman $\mathrm{R}=0.79,0.75$ and 0.60 , respectively, $\mathrm{p} \leq 0.001$ ) as well as $\mathrm{NH}_{3}$

255 oxidation (Spearman $\mathrm{R}=0.56, \mathrm{p} \leq 0.01$ ) (Table 2 ). This suggests that the lateral distribution of $\mathrm{N}$-cycling activity, including anammox, is mainly determined by the export of organic matter, which is the ultimate source of the required reactive substrates $\mathrm{NH}_{4}{ }^{+}$and $\mathrm{NO}_{2}{ }^{-}$in the $\mathrm{OMZ}$.

Overall, we estimate NPP of 12 and $47 \mathrm{Tg} \mathrm{N} \mathrm{y}^{-1}$ in the coastal and offshore surface waters, respectively, which appear reasonable at a net lateral supply of $88 \mathrm{Tg} \mathrm{NO}_{3}^{-} \mathrm{y}^{-1}$ to the 260 upwelling region (Fig. 3). The corresponding export fluxes are 4.4 and $9.9 \operatorname{Tg} \mathrm{N}_{\text {org }} \mathrm{y}^{-1}$. Taking organic matter sedimentation and export to the deep ocean into account, our results show that the export production to the OMZ is sufficient as an N-source to support the measured N-fluxes.

In summary, extensive sampling and experimentation throughout the ETSP OMZ 265 shows that the activity of anammox and N-linked processes is highly correlated with export production. High productivity over the shelf and upper slope, as well as sedimentary $\mathrm{NH}_{4}^{+}$ release, drive high rates of tightly coupled $\mathrm{N}$-cycling processes and thus $\mathrm{N}$-loss via anammox in the shallow coastal OMZ compared to the offshore OMZ.

While the globally expanding OMZs might increase the oceanic volume conducive to $270 \mathrm{~N}$-loss, N-loss would only continue to rise as long as there is sufficient nutrient supply for primary production in the euphotic zone, and nutrient supply is not hampered by intensified stratification (i.e. reduced upwelling) due to ocean warming. These positive and negative 
feedbacks are important considerations for biogeochemical models, which at present do not adequately reproduce the observed spatial patterns of N-loss in OMZs. In light of our results, the activities of N-loss via anammox appear to be directly linked to export production rates in biogeochemical models using the following empirical relationship: anammox $=0.7 \times \mathrm{N}_{\text {org }}$ export (supplementary Fig. 4). This may facilitate a realistic assessment of the short- and long-term impacts of ocean de-oxygenation and changing productivity on $\mathrm{N}$-cycling in OMZs, as well as their effects on neighbouring water masses.

\section{Materials \& Methods}

\section{Physico-chemical and $\mathrm{N}$-cycling rate measurements}

Large-scale distributions of chemical and biological variables were determined during the cruises M77-3 and 4 from December 2008 to February 2009 onboard R/V Meteor.

285 Seawater was collected with either a conductivity-temperature-depth (CTD) rosette system fitted with 10-L Niskin bottles or a pump-CTD system (depth range: $\sim 375 \mathrm{~m}$ ). Continuous vertical profiles of chlorophyll- $a$ were obtained fluorometrically and calibrated against discrete values derived from acetone extraction. Oxygen was measured with a Seabird sensor, a conventional amperometric microsensor and a highly sensitive STOX (Switchable Trace amount Oxygen) sensor ${ }^{39}$ (detection limit: $50 \mathrm{nmol} \mathrm{L}^{-1}$ ). Dissolved inorganic $\mathrm{N}$ and $\mathrm{PO}_{4}{ }^{3-}$ concentrations were analyzed using standard protocols ${ }^{45,46}$. Nitrogen deficits were calculated as $\mathrm{N}^{*}$ following Gruber \& Sarmiento ${ }^{47}$. Rates of microbial $\mathrm{N}$-cycling $\left(\mathrm{NH}_{3}\right.$ and $\mathrm{NO}_{2}{ }^{-}$ oxidation, $\mathrm{NO}_{3}{ }^{-}$reduction, anammox, denitrification and DNRA) were determined in shortterm, time-series incubation experiments with various combinations of ${ }^{15} \mathrm{~N}$-labeled and

295 unlabelled compounds as described in Füssel et al. ${ }^{22}$ and Holtapples et al. ${ }^{48}$. Oxygen sensitivity assays for $\mathrm{NO}_{2}{ }^{-}$oxidation were conducted as previously described ${ }^{22}$. Consistent rates for anammox were calculated from the various ${ }^{15} \mathrm{~N}$-incubation experiments 
$\left({ }^{15} \mathrm{NH}_{4}{ }^{+} \pm{ }^{14} \mathrm{NO}_{2}{ }^{-},{ }^{15} \mathrm{NO}_{2}{ }^{-}{ }^{14} \mathrm{NH}_{4}{ }^{+},{ }^{15} \mathrm{NO}_{2}{ }^{-}{ }^{14} \mathrm{NH}_{4}{ }^{+}\right)$for coastal OMZ stations; whereas more variability was associated with offshore OMZ stations. Although the possibility of substrate stimulation due to ${ }^{15} \mathrm{~N} /{ }^{14} \mathrm{~N}$-amendments cannot be fully eliminated, marine microbes including anammox and nitrifying bacteria ${ }^{13,22}$ are often associated with particles, and thus can experience substrate concentrations several orders of magnitude greater than the ambient water ${ }^{49}$ such that our measured rates could also be substantially underestimated. In order to examine whether the export production is sufficient to support these measured rates of various subsurface $\mathrm{N}$-cycling processes and ultimately $\mathrm{N}$-loss, the maximum potential rates for anammox from the various isotope-amendments (Supplementary Table 2) were used in budget calculations. Based on our combined rate measurements, nutrient inventories and subsequent modeling, the $\mathrm{N}$-fluxes are sufficient to support all measured rates of $\mathrm{N}$ transformation. Hence, the here-presented measured rates may not be too far from reality.

\section{Molecular ecological analyses}

Water samples for nucleic-acids-based analyses were collected onto polyethersulfone membrane filters $(0.2 \mu \mathrm{m}$; Millipore $)$ and immediately frozen at $-80^{\circ} \mathrm{C}$ until further analysis. Nucleic acids were extracted using a Qiagen DNA/RNA All prep Kit following the

315 manufacturers protocol with minor modifications ${ }^{50}$. Functional genes for archaeal and bacterial ( $\beta$ - $/ \gamma$-proteobacterial) $\mathrm{NH}_{3}$ oxidation (arch-amo $A$ and $\beta$ - $/ \gamma$-amoA, respectively), anammox (hzol and 2), denitrification (denitrifier-nirS) and DNRA (nrfA) were PCRamplified as described in Löscher et al. ${ }^{49}$. Standards for quantitative PCRs were obtained from: Nitrosococcus oceani NC10 and Nitrosomonas marina NM22 and NM51 ( $\gamma$ - and $\beta$ 320 amoA, respectively), an environmental clone (GenBank accession number JF796147; archamoA), Candidatus "Scalindua profunda" (hzo1 and 2), Pseudomonas aeruginosa PAO1 (denitrifier-nirS) and Escherichia coli $\mathrm{K} 12$ (nrfA). 


\section{Modeling of export production}

Export production was calculated from estimates of net primary production and the ratio of export production to total primary production (ef-ratio). Net primary production (NPP) at the time and location of our experimental stations was computed from measured chlorophyll-a concentrations and satellite-based (MODIS ocean color data) estimates of photosynthetic available radiation using the Vertically Generalized Production model ${ }^{42}$. Ef-

330 ratios were calculated from NPP and measured surface temperatures after Laws et al. ${ }^{43}$.

\section{Author contributions}

TK, GL and MK designed the study. TK, GL, SC and AP performed ${ }^{15} \mathrm{~N}$-labeling 335 experiments. TK, GL and PL analyzed the data. CL carried out functional gene analyses. LA and AO modelled export production rates. LS provided CTD and ADCP data. TK, GL, PL and MK wrote the manuscript.

The authors declare no competing financial interests.

\section{References}

1. Kamykowski, D. \& Zentara, S. Hypoxia in the world ocean as recorded in the historical data set. Deep-Sea Res. 37, 1861-1874 (1990).

2. Karstensen, J., Stramma, L. \& Visbeck, M. Oxygen minimum zones in the eastern tropical Atlantic and Pacific oceans. Progr. Oceanogr. 77, 331-350 (2008). 
3. Diaz, R.J. \& Rosenberg, R. Spreading Dead Zones and Consequences for Marine Ecosystems. Science 321, 926-929 (2008).

350 4. Stramma, L. et al. Expanding Oxygen-Minimum Zones in the Tropical Oceans. Science 320, 655-658 (2008).

5. Keeling, R.F., Körtzinger, A. \& Gruber, N. Ocean Deoxygenation in a Warming World. Ann. Rev. Mar. Sci. 463-493 (2009).

6. Lam, P. \& Kuypers, M.M. Microbial Nitrogen Cycling Processes in Oxygen 355 Minimum Zones. Ann. Rev. Mar. Sci. 3, 317-347 (2011).

7. Gruber, N. The Dynamics of the Marine Nitrogen Cycle and its Influence on Atmospheric CO2. NATO ASI Series 97-148 (2004).

8. Deutsch, C. et al. Climate-Forced Variability of Ocean Hypoxia. Science 333, 336-339 (2011).

3609 9. Moore, J.K. \& Doney, S.C. Iron availability limits the ocean nitrogen inventory stabilizing feedbacks between marine denitrification and nitrogen fixation. Glob. Biogeochem. Cyc. 21, GB2001 (2007).

10. Schmittner, A. et al. Future changes in climate, ocean circulation, ecosystems, and biogeochemical cycling simulated for a business-as-usual $\mathrm{CO} 2$ emission scenario until year 4000 AD. Glob. Biogeochem. Cyc. 22, GB1013 (2008).

11. Somes, C.J. et al. Simulating the global distribution of nitrogen isotopes in the ocean. Glob. Biogeochem. Cyc. 24, GB4019 (2010).

12. Kuypers, M.M. et al. Massive nitrogen loss from the Benguela upwelling system through anaerobic ammonium oxidation. PNAS 102, 6478-6483 (2005).

370 13. Hamersley, M.R. et al. Anaerobic ammonium oxidation in the Peruvian oxygen minimum zone. Limnol. Oceanogr. 52, 923-933 (2007). 
14. Jensen, M.M. et al. Intensive nitrogen loss over the Omani Shelf due to anammox coupled with dissimilatory nitrite reduction to ammonium. ISME AOP (2011).

15. Lam, P. et al. Origin and fate of the secondary nitrite maximum in the Arabian Sea. Biogeosciences 8, 1565-1577 (2011).

16. Bohlen, L. et al. Benthic nitrogen cycling traversing the Peruvian oxygen minimum zone. Geoch. Cosmoch. Acta 75, 6094-6111 (2011).

17. Cline, J.D. \& Richards, F.A. Oxygen Deficient Conditions and Nitrate Reduction in the Eastern Tropical North Pacific Ocean. Limnol. Oceanogr. 17, 885-900 (1972).

380 18. Codispoti, L.A. \& Packard, T.T. Denitrification Rates in the Eastern Tropical SouthPacific. J. Mar. Res. 38, 453-477 (1980).

19. Naqvi, S.W. Some aspects of the oxygen-deficient conditions and denitrification in the Arabian Sea. J. Mar. Res. 45, 1049-1072 (1987).

20. Thamdrup, B. et al. Anaerobic ammonium oxidation in the oxygen-deficient waters off northern Chile. Limnol. Oceanogr. 51, 2145-2156 (2006).

21. Lam, P. et al. Revising the nitrogen cycle in the Peruvian oxygen minimum zone. PNAS 106, 4752-4757 (2009).

22. Füssel, J. et al. Nitrite oxidation in the Namibian oxygen minimum zone. ISME AOP (2011).

390 23. Lipschultz, F. et al. Bacterial transformations of inorganic nitrogen in the oxygendeficient waters of the Eastern Tropical South Pacific Ocean. Deep-Sea Res. 37, 15131541 (1990).

24. Kalvelage, T. et al. Oxygen Sensitivity of Anammox and Coupled N-Cycle Processes in Oxygen Minimum Zones. PLoS ONE 6, e29299 (2011).

395 25. Fuenzalida, R. et al. Vertical and horizontal extension of the oxygen minimum zone in the eastern South Pacific Ocean. Deep-Sea Res. II 56, 992-1003 (2009). 
26. Codispoti, L.A. \& Christensen, J.P. Nitrification, Denitrification and Nitrous Oxide Cycling in the Eastern Tropical South Pacific Ocean. Marine Chemistry 16, 277-300 (1985).

400 27. Wooster, W.S., Chow, T.J. \& Barrett, I. Nitrite Distribution in Peru Current Waters. $J$. Mar. Res. 23, 210-221 (1965).

28. Nelson, S.S. \& Neshyba, S. On the southernmost extension of the Peru-Chile Undercurrent. Deep-Sea Res. 26A, 1387-1393 (1979).

29. Ward, B.B., Glover, H.E. \& Lipschultz, F. Chemoautotrophic Activity and Nitrification in the Oxygen Minimum Zone off Peru. Deep-Sea Res. 36, 1031-1051 (1989).

30. Fernández, C., Farías, L. \& Alcaman, M.E. Primary production and nitrogen regeneration processes in surface waters of the Peruvian upwelling system. Progr. Oceanogr. 83, 159-168 (2009).

410 31. Anderson, J.J. et al. A model for nitrite and nitrate distributions in oceanic oxygen minimum zones. Deep-Sea Res. 29, 1113-1140 (1982).

32. Lavik, G. et al. Detoxification of sulphidic African shelf waters by blooming chemolithotrophs. Nature 457, 581-584 (2008).

33. Dalsgaard, T. et al. Anammox and denitrification in the oxygen minimum zone of the eastern South Pacific. Limnol. Oceanogr. 57, 1331-1346 (2012).

34. Ward, B.B. et al. Denitrification as the dominant nitrogen loss process in the Arabian Sea. Nature 461, 78-81 (2009).

35. Deutsch, C. et al. Denitrification and N2 Fixation in the Pacific Ocean. Glob. Biogeochem. Cyc. 15, 483-506 (2001).

420 36. Dalsgaard, T. et al. N2 production by the anammox reaction in the anoxic water column of Golfo Dulce, Costa Rica. Nature 422, 606-608 (2003). 
37. Van Mooy, B.A., Keil, R.G. \& Devol, A.H. Impact of suboxia on sinking particulate organic carbon: Enhanced carbon flux and preferential degradation of amino acids via denitrification. Geoch. Cosmoch. Acta 66, 457- 465 (2002).

425 38. Canfield, D.E. et al. A Cryptic Sulfur Cycle in Oxygen-Minimum Zone Waters off the Chilean Coast. Science 330, 1375-1378 (2010).

39. Revsbech, N.P. et al. Determination of ultra-low oxygen concentrations in oxygen minimum zones by the STOX sensor. Limnol. Oceanogr.: Methods 7, 371-381 (2009).

40. Thamdrup, B., Dalsgaard, T. \& Revsbech, N.P. Widespread functional anoxia in the oxygen minimum zone of the eastern South Pacific. Deep-Sea Res. I in Press (2012).

41. Bertrand, A., Ballón, M. \& Chaigneau, A. Acoustic Observation of Living Organisms Reveals the Upper Limit of the Oxygen Minimum Zone. PLoS ONE 5, e10330 (2010).

42. Behrenfeld, M.J. \& Falkowski, P.G. Photosynthetic rates derived from satellite-based chlorophyll concentration. Limnol. Oceanogr. 42, 1-20 (1997).

435 43. Laws, E.A. et al. Temperature effects on export production in the open ocean. Glob. Biogeochem. Cyc. 14, 1231-1246 (2000).

44. Pennington, J.T. et al. Primary production in the eastern tropical Pacific: A review. Progr. Oceanogr. 69, 285-317 (2006).

45. Grasshoff, K. et al. Methods of seawater analysis. (Wiley: 1999).

440 46. Holmes, R.M. et al. A simple and precise method for measuring ammonium in marine and freshwater ecosystems. Canadian Journal of Fisheries and Aquatic Sciences 56, 1801-1808 (1999).

47. Gruber, N. \& Sarmiento, J.L. Global Patterns of Marine Nitrogen Fixation and Denitrification. Glob. Biogeochem. Cyc. 11, 235-266 (1997). 
445 48. Holtappels, M. et al. 15N-labeling experiments to dissect the contributions of heterotrophic denitrification and anammox to nitrogen removal in the OMZ waters of the ocean. Methods Enzymol. 486, 223-251 (2011).

49. Stocker, R. Marine Microbes See a Sea of Gradients. Science 338, 628-633 (2012).

50. Loescher, C.R. et al. Production of oceanic nitrous oxide by ammonia-oxidizing archaea. Biogeosc. Disc. 9, 2095-2122 (2012). 
Correspondence and requests for materials should be directed to: mkuypers@mpi-bremen.de

455

\section{Acknowledgements}

We wish to thank the Peruvian government for access to their territorial waters. We sincerely thank cruise leader Martin Frank as well as the crews of the cruises M77-3 and 4

460 onboard $R / V$ Meteor for their support at sea. We are grateful for the technical and analytical assistance of Gabriele Klockgether, Inka Boosmann, Violeta Leon, Imke Grefe and Andreas Ellrott. We thank Niels Peter Revsbech, who generously provided the STOX sensors and Tim Ferdelmann for offering valuable comments to improve the article. This study was supported by the Deutsche Forschungsgemeinschaft through the Sonderforschungsbereich 754

465 "Climate-Biogeochemistry Interactions in the Tropical Ocean" and the Max Planck Society. 


\section{Table 1 | Abundance of selected N-functional genes and N-conversion rates in the ETSP during cruise M77-3.}

Functional genes and N-conversion rates were not always determined at the same station and/or depths but with a comparable latitudinal and longitudinal as well as vertical resolution.

\begin{tabular}{|c|c|c|c|c|c|c|c|c|c|c|c|c|c|c|}
\hline & & \multicolumn{7}{|c|}{$\mathrm{N}$-functional gene abundances $\left(10^{2}\right.$ copies $\left.\mathrm{mL}^{-1}\right)$} & \multicolumn{6}{|c|}{ N-conversion rates $\left(\mathbf{n m o l} \mathbf{N ~ L}^{-1} \mathbf{d}^{-1}\right)$} \\
\hline & & $\operatorname{arch}-\operatorname{amoA}$ & $\beta$-amoA & $\gamma$-amoA & hzo1 & hzo2 & den-nirS* & nrfA & $\mathrm{NH}_{3} \mathbf{o x}$ & Anammox & $\begin{array}{l}\text { Denitri- } \\
\text { fication }\end{array}$ & DNRA & $\mathrm{NO}_{2}^{-} \mathrm{ox}$ & $\mathrm{NO}_{3}^{-}$red. \\
\hline \multirow{4}{*}{ 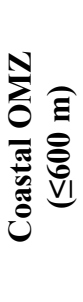 } & N: & $63(64)$ & $8(49)$ & $0(64)$ & $8(64)$ & $42(64)$ & $0(63)$ & $0(64)$ & $27(33)$ & $33(33)$ & $3(33)$ & $7(33)$ & $27(32)$ & $27(32)$ \\
\hline & Range: & $0.16-2773$ & $0.05-1056$ & - & 0.05-0.09 & $0.14-12.8$ & - & - & $0.22-48.8$ & $2.84-227$ & $2.21-5.42$ & $0.48-1.74$ & $8.48-928$ & $3.79-1010$ \\
\hline & Mean: & 676 & 135 & - & 0.07 & 4.45 & - & - & 8.24 & 43.4 & 4.19 & 1.14 & 172 & 203 \\
\hline & Median: & 90 & 5.0 & - & 0.06 & 3.77 & - & - & 3.40 & 21.2 & 4.94 & 1.10 & 65.4 & 101 \\
\hline \multirow{4}{*}{ 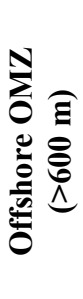 } & N: & $67(71)$ & $2(33)$ & $0(72)$ & $4(71)$ & $43(72)$ & $2(72)$ & $1(72)$ & $17(40)$ & $33(40)$ & $0(40)$ & $3(40)$ & $27(40)$ & $25(34)$ \\
\hline & Range: & $0.04-2332$ & $0.15-1.36$ & - & 0.01-0.09 & $0.06-14.7$ & $0.06-1.98$ & 0.11 & $0.51-88.8$ & $0.71-46.9$ & - & $0.33-1.31$ & $4.58-186$ & $4.53-77.4$ \\
\hline & Mean: & 352 & 0.75 & - & 0.08 & 3.15 & 1.02 & 0.11 & 20.9 & 6.14 & - & 0.82 & 40.6 & 32.1 \\
\hline & Median: & 89.5 & 0.75 & - & 0.08 & 1.51 & 1.02 & 0.11 & 5.79 & 3.01 & - & 0.83 & 30.2 & 22.3 \\
\hline
\end{tabular}

$\mathrm{N}=$ number of samples in which $\mathrm{N}$-functional genes/N-processes were detected; in parenthesis: number of samples analyzed.

*denitrifier-nirS. 
Table 2 | Spearman rank correlation of depth-integrated nutrients and $\mathrm{N}$-cycling rates as well as modelled export productions.

\begin{tabular}{|c|c|c|c|c|c|}
\hline & $\begin{array}{c}\mathrm{NH}_{3} \\
\text { oxidation }\end{array}$ & $\begin{array}{c}\mathrm{NO}_{2}^{-} \\
\text {oxidation }\end{array}$ & $\begin{array}{c}\mathrm{NO}_{3}^{-} \\
\text {reduction }\end{array}$ & Anammox & $\begin{array}{c}\text { Export } \\
\text { Production }\end{array}$ \\
\hline $\mathrm{NH}_{4}{ }^{+}$ & $0.51 *$ & 0.31 & 0.08 & 0.30 & 0.29 \\
\hline $\mathrm{NO}_{2}^{-}$ & $0.46^{*}$ & $0.49 *$ & $0.71 * * *$ & $0.64 * *$ & 0.10 \\
\hline $\mathbf{N *}$ & -0.08 & -0.20 & -0.05 & -0.02 & -0.02 \\
\hline Export Production & $0.56^{*}$ & $0.60 * *$ & $0.75 * * *$ & $0.79 * * *$ & \\
\hline Anammox & $0.75 * * *$ & $0.86 * * *$ & $0.88 * * *$ & & \\
\hline $\mathrm{NO}_{3}^{-}$reduction & $0.49 *$ & $0.75 * * *$ & & & \\
\hline $\mathrm{NO}_{2}^{-}$oxidation & $0.73 * * *$ & & & & \\
\hline
\end{tabular}

5

Presented values are correlation coefficients with significant values denoted by $*(\mathrm{p} \leq 0.05), * *(\mathrm{p} \leq 0.01)$ and $* * *(\mathrm{p} \leq 0.001)$. 


\section{Figure legends}

\section{Figure 1 | Maps of sampling locations and nutrient distributions in the ETSP}

OMZ. a, Sampling sites during M77-3 (•) and M77-4 (•) and ${ }^{15} \mathrm{~N}$-experimental stations $(\bullet)$. b, vertical extent of the OMZ (in $\mathrm{m}$ ) as defined by $\mathrm{O}_{2} \leq 15 \mu \mathrm{mol} \mathrm{L}{ }^{-1}$. c-f, concentrations of $\mathrm{NO}_{3}{ }^{-}, \mathrm{NO}_{2}^{-}, \mathrm{NH}_{4}^{+}$and $\mathrm{N}^{*}\left(\right.$ in mol m${ }^{-2}$ ) integrated over the thickness of the OMZ. Red line in panel a. denotes the $600 \mathrm{~m}$-isobath that was used demarcate the coastal OMZ from offshore OMZ.

Figure 2 | Depth-integrated N-cycling rates in the ETSP OMZ. a,b, the two steps of the aerobic nitrification, $\mathrm{NH}_{3}$ oxidation and $\mathrm{NO}_{2}{ }^{-}$oxidation. $\mathbf{c}, \mathrm{NO}_{3}{ }^{-}$reduction to $\mathrm{NO}_{2}{ }^{-}$. d,e, $\mathrm{N}$-loss due to anammox as well as denitrification coupled to the oxidation of $\mathrm{H}_{2} \mathrm{~S}$ during a sulfidic event on the Peruvian shelf. $\mathbf{f}$, modelled export of organic $\mathrm{N}$ from the euphotic zone to the OMZ. All rates in mmol $\mathrm{N} \mathrm{m}^{-2} \mathrm{~d}^{-1}$.

Figure $3 \mid$ N-fluxes and nutrient inventory of the ETSP OMZ. Black numbers indicate inventories of dissolved inorganic nitrogen (in $\mathrm{Tg} \mathrm{N}$ ). They were derived from the depth-integrated values over the OMZ thickness shown in Figs. 1-2, and then based on the $600 \mathrm{~m}$ seafloor depth cut-off for coastal versus offshore OMZs, the depth-integrated values were further integrated over the areal extents of the two types of OMZs. Fluxes (in $\mathrm{Tg} \mathrm{N} \mathrm{y}^{-1}$ ) within the OMZ or across its boundaries are given in colour and white, respectively. A detailed description of the flux calculations is included in the supplementary information. 


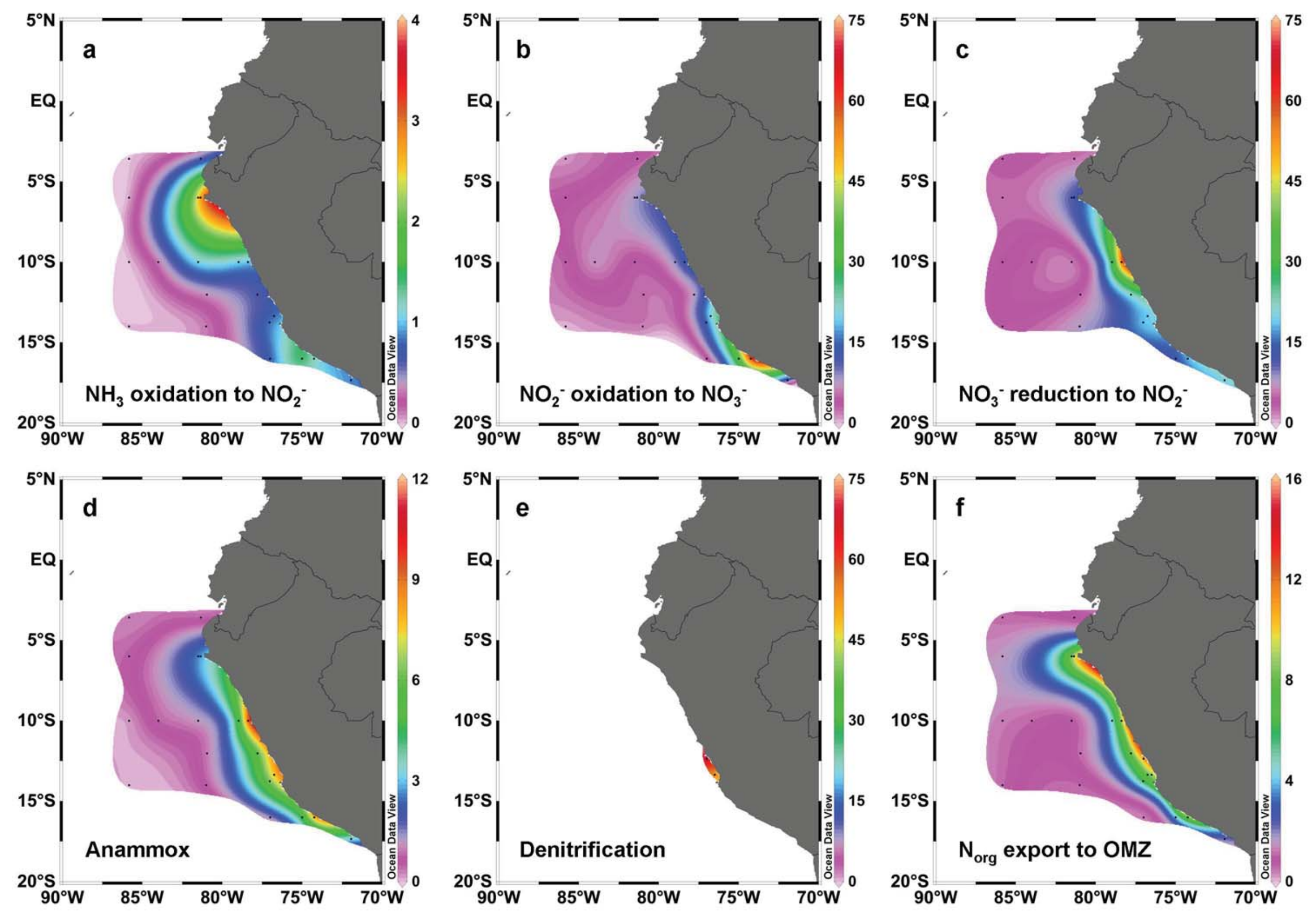




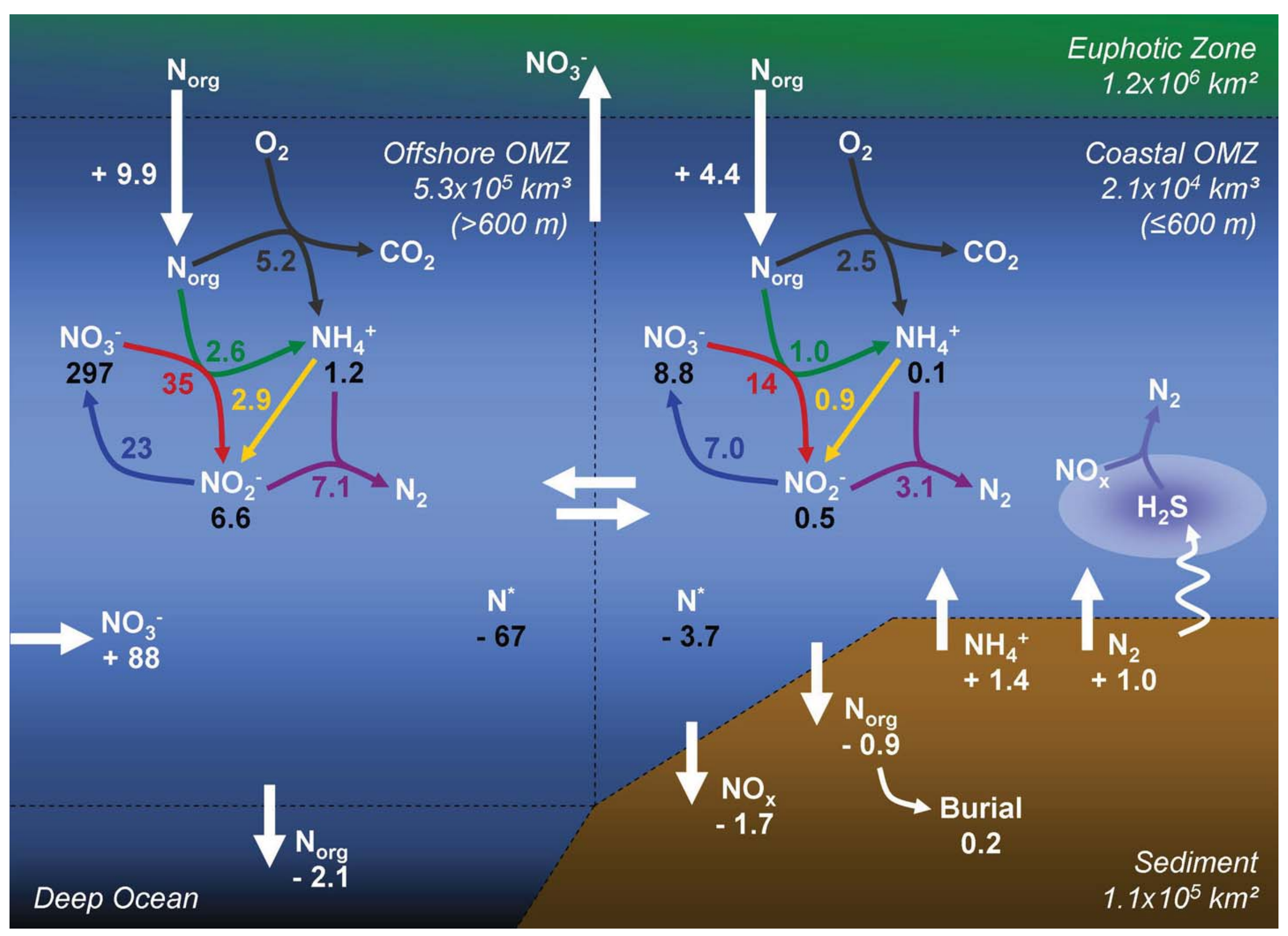

